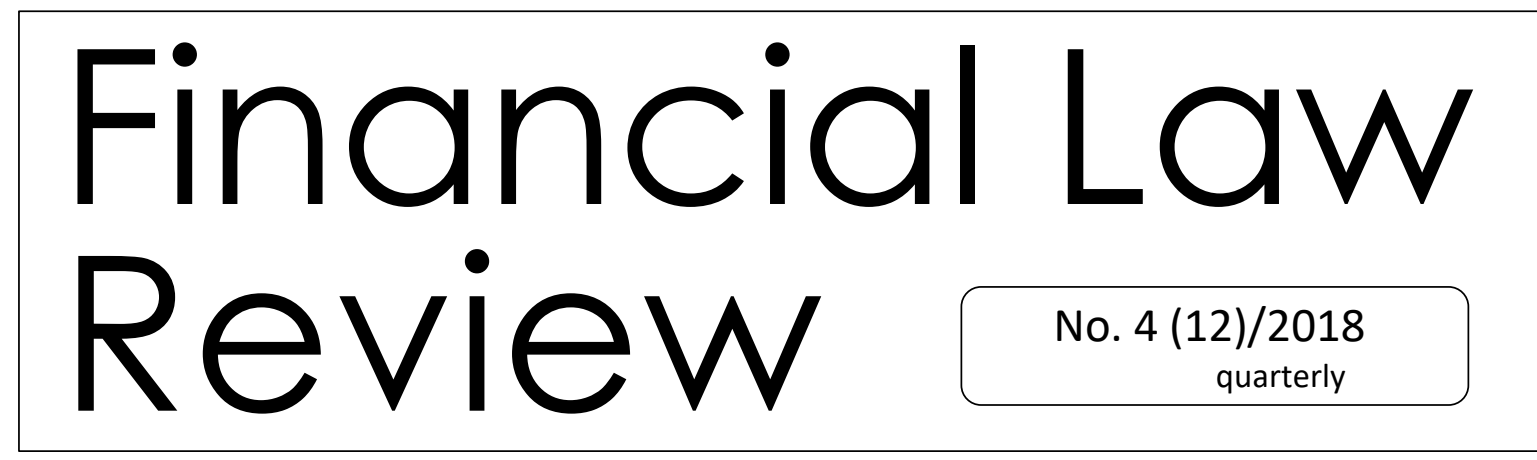

UNIVERSITY OF GDAŃSK • MASARYK UNIVERSITY • PAVEL JOZEF ŠAFÁRIK UNIVERSITY • UNIVERSITY OF VORONEZH http://www.ejournals.eu/FLR

\title{
REGULATIONS AND CORPORATE GOVERNANCE PRINCIPLES STRENGTHENING THE EFFECTIVENESS OF INTERNAL CONTROL, COMPLIANCE AND AUDIT IN THE CAPITAL GROUP ${ }^{1}$ \\ SEBASTIAN SKUZA*, ROBERT LIZAK*
}

\begin{abstract}
The introduction of the so-called holding law into domestic law has been discussed in Poland for some time now. The need to adopt a holding law seems to be unquestionable, however no amendments in this scope have been introduced hitherto. The aim of this article was to discuss mechanisms of corporate governance compliant with Polish law, allowing for improvements in proficiency and effectiveness of audit, internal control and compliance win a capital group. In the Authors' opinion, these issues not only play key role in common achieving of economic aims by capital group mentioned previously, but they are also a part of supranational need of increasing transparency and security of market economy. Also, it seems unquestionable that a de lege ferenda postulate should be submitted concerning introduction of solutions in the scope of the so-called holding law in the law - Code of commercial companies.
\end{abstract}

Key words: Audit, compliance, corporate governance, internal control, capital group

\footnotetext{
${ }^{1}$ This publication was prepared as part of the NCN Opus 11 HS5 research project Compliance jako narzędzie zapobiegania korupcji (Compliance as a tool of corruption prevention), carried out at the Institute of Law Studies of the Polish Academy of Sciences.

* Sebastian Skuza, PhD with habilitation, University of Warsaw Management Faculty.

* Robert Lizak, PhD, Institute of Law Studies of the Polish Academy of Sciences.
} 


\section{JEL Classification: G32, G34, K12, K15, K22, K42}

\section{Introduction}

Capital group is common and popular form of conducting business activity in a market economy, in particular among entities of significant scale of activity they engage in [Gajewski 2005: 13-17]. Key factor determining creation of a capital group is the willingness to increase effectiveness of conducted activity, which makes it easier to achieve assumed goals. It is irrelevant whether the goal is to maximize profit or to secure public interest in case of entities oriented at implementation of a public mission [The law on principles of managing state property 2016]. Regardless of ownership structure and the basic purpose of operation of particular entities, capital group gives opportunity to improve activity in almost all areas, in particular in the scope of management, organization, operations, finances and law [Nogalski, Waśniewski, Miklaszewska 2013: 237].

The introduction of the so-called holding law into domestic law has been discussed in Poland for some time now [Kwaśnicki, Nilsson 2007: 26-32; Romanowski 2008: 3-12; Sołtysiński 2008: C3]. In 2009 and 2010 some drafts of novelization of the law - Code of commercial companies in this scope emerged [cf: the draft law of 29 July 2009 and of 22 March 2010]. The need to adopt holding law seems unquestionable, however novelization to this effect has not been adopted hitherto.

In this case we are dealing with a classical example of how legal provisions are outpaced by business activity practice. The essence of business activity to some extent necessitates undertaking activities in areas not regulated by the provisions of law, which resulted in the emergence of solutions based on the principles of corporate governance, allowing for improvements in proficiency and effectiveness of audit, internal control and compliance in particular areas of activity of companies in capital group. This article describes existing mechanisms in the scope of audit, internal control and compliance.

\section{The notion and essence of capital group}

Legal doctrine defines group of companies as a new economic organism, created by at least two capital companies, bound by a dominance and dependence relation - whereas lack of separate legal personality of thus created group is stressed. Business goal of the group, as well as of its constitutive entities is set out by dominant company [Zięba 2016; Romanowski 2008: 5].

There are two approaches proposed by holding law:

- comprehensive regulation, 
- lack of regulation, possibly residua regulation.

The first approach was, for example, adopted in Germany, the second one - in the United States. German legislation provides holding provisions in $\$ 291-337$ of Aktiengesetz of 6 September 1965. In the American system issues pertaining to holding law are regulated by judicial rulings or doctrine. The most famous is Rozenblum's case, i.e. permissibility of ad hoc 'sacrificing' interest of subsidiary in order to protect interest of grup of companies, if in the long-term the subsidiary's share in the group is beneficial) [Justification to the draft law of 28 July 2009 amending the Law - Code of commercial companies; Szumański in Filsek 2011: XVI).

In Polish law notion of capital group is quite specific. Although the notion of capital group in the scope of commercial law is significant, the Law - Code of commercial companies does not define it, let alone refer to it. The same applies to definitions and notions with which capital group is quite often identified, i. e. holding, consortium or group of companies. Provisions of the law of commercial companies in the scope of commercial law are limited to defining in the Law - Code of commercial companies of the notion of dominant company (article $4 \S 1 \S 4$ ), establishing scope of obligations of such company (article 6), and matters related to agreements between dominant company and subsidiary in the scope of managing the subsidiary by the dominant company and transferring profit by the subsidiary (article 7). To sum up, the provisions of the Law - Code of commercial companies is an example of limited regulation of holding law [Justification to the draft law of 28 July 2009 amending the Law - Code of commercial companies].

As for the notion of 'capital group' as defined in universally binding provisions of domestic law other than the Law - Code of commercial companies, a specific profusion is noticeable. For example, the notion in question is present in the Law on accounting (article 3 (1) §44), the Law on the protection of competition and consumers (article $4 \$ 14$ ), the Law on corporate tax (article 1a), the Law on trading financial instrument (article $3 \$ 18$ ), the Law on public procurement (article $24 \$ 23$ ), the Law on particular rights of minister competent for energy matters and their execution in some capital companies or capital groups conducting business activity in sectors of electricity, petroleum and gas fuels (article $1 \$ 1$ ).

As duly noticed by D. Gajewski, the notion of capital group is not identical in each of these laws, since the legislator assumed various goals in creating each of those regulation. For example, the main aim of defining tax capital group was to trigger certain tax consequences, whereas definition of capital group on the grounds of the Law on accounting was introduced in or-der to present financial report by a group of related companies [Gajewski 2005: 25].

The essence of capital group seems to consists in formal or informal relation between at least two companies aimed at exercising control of one company over another company in 
all aspects of activity, which allows for more proficient and effective pursue of common economic interest [Kot, Stokłosa 2015: 16-20; Kondrakiewicz 2001: 171-177; Piszcz 2013: 44-55]. In order to define capital group in a manner reflecting its essence, the following proposition should be considered of a normative definition of group of companies in the already mentioned draft law amending the Law - Code of commercial companies and the Law on the National Court Register. Pursuant to article $4 \$ 1 \S 5^{1}$ of this draft law, group of companies consists of 'dominant company and subsidiary or subsidiaries, remaining in real or contractual permanent organizational relation and sharing common economic interest'.

\section{Internal control, compliance and audit}

Internal control may be defined as activity consisting in checking the correct-ness of the course of internal processes against intended goal [Saunders 1996: 17-28; Oplustil 2010: 375-382]. Compliance, in turn, is a set of coordinated elements intentionally establishing manner of conduct in universally and internally binding provisions of law, as well as in accepted value and corporate culture and governance. Legal regulations in the scope of compliance were introduced for the first time in the United States as a result of adopting the Foreign Corrupt Practices Act in 1977 [Barcik 2016: 11]. B. Makowicz defines compliance as 'organization of enterprise, which, by creating relevant structure and applying means of compliance, maximally reduces the risk of occurrence in the enterprise any inconsistencies which could appear as a result of actions of adherent persons or business partners, constituting in breaching binding legal regulations and general principles of law, regulations freely adopted by the enterprise or actions incompatible with ethical and moral standards generally applied in a given environment' [Makowicz 2011: 15-19]. Internal audit is an independent and objective activity, the aim of which is to add values and improve operations of the organization [Czerwiński 2004: 21-23; Anczakowski 2008: 103-114; Ciak, Voss 2017: 235-254].

All the above mentioned areas display at least three common features, which are significant for the functioning of company or group of companies. Firstly, internal control, compliance and audit facilitate, or even make it possible to pursue economic interest stated in the capital group agreement, especially in the scope of avoiding loss, counteracting and fighting abuse. Secondly, the essence of functioning of internal control, compliance and audit is based on fact-finding. The more fact-findings there are, the more feasible the decision-making process becomes, and the more proficient and effective system of protection against threats and risks in capital group is. Thirdly, all these three elements belong to a popular model of three lines of defense [Braun 2017: 148-150]. The first line of defense consists of operational activity aimed at achieving certain economic interest, in the scope of ordinary management. Since such activities generate risks that may block or impede achieving the economic interest, internal control is a remedy for those risks. The 
second line of defense fulfills a service function towards management and the first line of defense. It covers financial control, quality management systems existing in the organization, IT security and compliance. The third line of defense is internal audit, which consists in independent assessment and improving efficiency of management processes.

When discussing internal audit, we should not forget about the institution of audit committee [Krauss 2012: 18-25; Wieczorek 2012: 309-340]. This institution has been present in the domestic legal order for many years [Recommendation of the Commission 2004/913/EC fostering an appropriate regime for the remuneration of directors of listed companies, Official Journal L 385/55 of 29.12.2004; The Good Practices in Public Companies 2002]. How-ever, recently a new law was introduced, namely the Law of 11 May 2017 on statutory auditors, audit companies and public supervision, the adoption of which was associated with the obligation to implement the Regulation (EU) No 537/2014 of the European Parliament and of the Council of 16 April 2014 on specific requirements regarding statutory audit of public-interest entities and repealing Commission Decision 2005/909/EC. The Regulation established new role and new tasks of the audit committee. Some authors claim that, based on the new law, three basic functions of the audit committee may be identified, i.e. preparatory function, supervisory and control function and information function. Preparatory function in the first place consists in developing policy of selecting auditing company and establishing procedure of selection. Supervisory and control function is mainly associated with monitoring the process of financial reporting, efficiency of the systems of internal control and the systems of risk management, as well as monitoring execution of financial revision. Information function of the audit committee consists in informing supervisory board of the results of conducted audit and explaining how it contributed to the reliability of financial reporting in the company, and also what the role of the audit committee was in the audit process [Pinior 2018: 259-269].

The above leads to two conclusions. Firstly, audit committee is very significant for establishing mechanism of corporate governance. Based on the review of its functions and tasks it may be assumed that supervisory board is the organ responsible for constant supervision in the company, in which is assisted by audit committee. Secondly, the aim of the new role and tasks of audit committee, combined with the previous role and tasks of supervisory board, is to significantly improve transparency and security of companies and groups of companies.

\section{Internal control, compliance and audit in capital group from perspective of management and supervisory board}

In domestic regulations of commercial law, dual model of managing capital group was established. This means that there is a distinction between organizational, personal and functional management and supervisory domain. The role of the management is to run all 
the company's affairs and its representation, unless they are restricted by a provision of law or contract, or the articles of association for another organ [article $368 \$ 1$ of the Law Code of commercial companies]. The role of supervisory board, in turn, comes down to executing constant supervision over the company's activity in all areas [article $382 \S 1$ of the Law - Code of commercial companies].

As was already mentioned, competences of the management cover managing all the affairs of the company and its representation. Such approach in the scope of division of competences gives the management of a capital company a relatively strong position. This also results from many management and representation obligations set out in the Law Code of commercial companies, which are executed independently by the management [Kidyba 2018]. This means that management is practically entirely free in creating organizational structure of the company, including tasks implemented by particular units or organizational elements. This freedom may be limited by provisions of universally binding law (hard law) and regulations without any binding force (soft law). The latter group includes guidelines, recommendations, sets of good practices, etc.

The Law - Code of commercial companies does not contain regulations directly ordering the management to institute internal control, audit and compliance in a capital company. Contraction of capital companies as legal persons is based on the assumption expressed in article 38 of the Law - Civil code, according to which entities conduct their activity with their organs in manner set out in the provisions of law and their articles of association. Legal capacity of capital group is exercised by its obligatory organ, which is the management, therefore it is the management which is responsible for the compliance of company's activity with law. The management is also obliged to act in the interest of the company and to protect its assets. The principle of legalism in internal and external terms may then constitute the basis for establishing compliance in a capital company. Legalism cannot be achieved without applying internal control. The situation is different in case of the already mentioned audit on the grounds of the new law of 11 May 2017 on statutory auditors, audit companies and public supervision. Pursuant to article 18 of the above mentioned law, in units of public interest there is an audit committee in the meaning of the Regulation of the European Parliament and of the Council (EU) no 537/2014. Members of the audit committee are appointed by the supervisory board or other supervisory or control organ from among members of this organ. Appointing audit committee in units of public interest is obligatory.

Regulations that seem to be missing from the provisions of Law - Code of commercial companies may be found in The Good Practices of GPW Listed Companies, which entered into force on 1 January 2016. The Good Practices are a set of principles of corporate governance and principles of con-duct which have impact on the relations between listed companies and the market environment, an important element of constructing 
competition position of the companies and significantly add to improving attractiveness of Polish capital market [The Good Practices of GPW Listed Companies 2016]. Although lack of application of the Practices does not cause any negative legal sanctions, it may be perceived as strong signal in the scope of construing corporate governance in capital companies and in consequence increases the risk of loss of reputation. In accordance with the Good Practices listed companies maintain efficient systems of: internal control, risk management and compliance, as well as efficient function of internal audit, corresponding with the size of the company and type and scale of conducted activity. Implementation and maintenance of efficient systems of internal control, risk management and the function of internal audit is the responsibility of the company's management [Good Practices 2016: 14].

In accordance with article 12 of the Law - Code of commercial companies, capital company is endowed with legal personality and becomes an individual subject acting via its organs at the moment of its entry in the register. Since the Law - Code of commercial companies does not regulate matters associated with capital group and relations between its constituent companies, the above mentioned principle applies to both dominant company and to subsidiary. Configuration and nature of such relations do not really matter, i.e. it is not important if they happen between the so-called parent company and a subsidiary or between the so-called sister companies. In national legislation there are no legal grounds enabling management of one of the companies in a capital group to exert any impact of the management of another company in such areas as internal control, compliance and audit. Therefore, in capital group internal control, audit and compliance may only be organized within a single company. For example, dominant company does not have right to conduct audit, internal control and compliance with one of its subsidiaries, nor in the entire group of companies. At this point it is worth to mention the question of personal data. In the literature of the subject there is a view that personal data collected by one company in a capital group cannot be shared with another company from the group. It is stressed that in the light of current provisions of law, entities from the capital group are treated as entities separate from data controller. For this reason, participating in a capital group is irrelevant from the point of view of the scope of right to process personal data in the sense that the right granted to the data controller is not extended to other entities in capital group [Krasuski, Skolimowska 2007: 64].

As was already mentioned, due to the fact that life 'outpaces' law, in capital companies there already exist mechanisms of corporate governance allowing for addressing current needs. One example is entering into agreements on the provision of services. In accordance with the principle of freedom of contact from article $353^{1}$ of the Law - Civil Code, each company from capital group may become party to agreement with any other company, irrespective of whether their relation is horizontal or vertical. 
The Law - Civil Code regulates a number of agreements consisting de facto in the provision of services (e.g. contract of specific work, commission contract or agency contract), however it does not include provisions concerning an agreement on the provision of services. This type of agreement should therefore be classified as innominate contract, which means it is not a nominate contract and it does not have an independent normative basis. In accordance with article 750 of the Law - Civil Code, provisions on commission apply to agreement on the provisions of services accordingly.

In the preamble to agreement on the provision of services in a capital group it is indicated that the intention of the parties is usually cooperation consisting in the provision of services by dominant company for the benefit of subsidiary in order to support business processes, achieve synergy effect and lower the costs of activity, create organizational and decision-making relations, and eventually enable undisturbed flow of information. Agreement on the pro-visions of services establishes the subject and areas of cooperation in which dominant company shall provide services, including audit, internal control and compliance. On the example of audit, those services may concern: planning audits, providing support in developing audit plan, monitoring audit implementation and audit plans. Agreement on the provisions of services may also include provisions concerning requesting documents, data and information from subsidiary, establishing coherent audit procedures, addressees of written audit reports and recommendations, and also establishing common registers of unreliable contractors and sharing data from such registers.

Moreover, in the agreement the parties should be obliged to keep all the information regarding themselves confidential, especially concerning their activity, customers, economic, marketing, commercial, technical, strategic, organizational or any other data with any economic value, which were passed between the parties in any form. The agreement should also cover issues typical for bilateral agreements, such as payment rules, transfer of copyright, manner of communication, duration and termination of the agreement and processing of personal data.

Advantages associated with signing agreements of this type include:

- opportunity to reduce operational costs,

- qualitative optimization of resources,

- supplementing resources shortages,

- releasing resources held by the enterprise to other, possibly more beneficial, enterprises,

- proficient and cost effective implementation of restructuring process, 
- implementation of tasks which are not possible to be implemented based solely on own resources,

- obtaining capital,

- risk diversification [Nogalski, Waśniewski, Miklaszewska 2013: 241-242].

Key matters discussed in this publication look different from the perspective of the supervisory board. As A. Kidyba rightly says, constant supervision executed by the board is not limited to certain, periodical management activities (such as financial reports on the company's activity), but also all the activities undertaken by the board in the financial year [Kidyba 2018]. From article $391 \$ 3$ of the Law - Code of commercial companies it can be inferred that general meeting may adopt a regulation of supervisory board setting out its organization and manner of performance. Based on the last part of this sentence, it may be assumed that manner of performance also concerns performance carried out by the supervisory board with assistance from external entities. Actions directly associated with constant supervision actually cover all the areas of activity of the company, e.g. economy, law, management, technology and specifics of market on which given capital company operates. Theoretically, each of the members of supervisory board should have expertise in the above mentioned realms, however resorting to external entities (e.g. court experts, experts, scientists, lawyers) in some situations is not excluded.

A civil law agreement can constitute legal basis for commissioning pro-vision of expert services, entered into by capital group and given entity [Szydło: 2013: 14-15]. The result of the duality of organs in capital company results in the lack of power of supervisory board to manage the company, therefore the board is not authorized to enter into agreements of this type. Supervisory board of a company may adopt a resolution in which it will impose on the management the obligation to enter into agreement with certain entity [Szydło: 2013: 15-18]. It is worth to notice that entering into agreement by management and external entity means that this entity will be given access to information on the company. In such case obtaining consent of the management for granting the access is obligatory, and it can be contained in the agreement commissioning certain activities from certain entity. This means that if an external entity carries out activities on the commission of supervisory board of dominant company, it cannot demand information and data from subsidiary belonging to the group.

\section{Conclusion}

Although in Poland capital groups are common, not only because of the functioning of supranational company groups but also many existing national capital groups, the Law Code of commercial companies still does not contain any provisions regarding the socalled holding law. In the doctrine a view prevails, that there are serious delays in the Polish 
commercial law as compared to legislation of other countries [Discussion in Przegląd Corporate Governance 2009: 176-178; Discussion in Przegląd Corporate Governance, 2010: 159-162]. The need to introduce changes in commercial law is also expressed by judicature. In the ruling of 3 December 2012 the Appeal Court in Katowice claimed that creating groups of companies, as not prohibited by law, is allowed, and from economic point of view or the perspective of economic assumptions of the state it is often even desirable [case V ACa 702/12]. In the view of the Appeal Court, decision of given company on formal accession to group associating other companies made in order to pursue common economic interest leads to subordinating activity to that common interest, which de facto means limiting independence by making strategic decisions based on economic situation in the country and in the world, in the interest of the entire group (i.e. all the member companies in the group). In this short thesis the Appeal Court not only presented the essence and aim of functioning of capital group, but also implied the significance of capital group on the supranational level. To put it simple, establishing a capital group facilitates achieving common economic interest and competitive advantage in strategic perspective. Review of numerous supranational regulations adopted recently, especially those concerning financial market (MiFID II/MiFIR, MAD II/MAR, PRIIPS, ESMA, $C R D I V, C R R)$ shows that they share at least one common feature - their goal is to increase transparency and security.

The aim of this article was to discuss mechanisms of corporate governance compliant with Polish law, allowing for improvements in proficiency and effectiveness of audit, internal control and compliance in a capital group. In the Authors' opinion, these issues not only play key role in common achieving of economic aims by capital group mentioned previously, but they are also a part of supranational need of increasing transparency and security of market economy. Also, it seems unquestionable that a de lege ferenda postulate should be submitted concerning introduction of solutions in the scope of the so-called holding law in the law - Code of commercial companies.

\section{References:}

Anczakowski M.: Charakter prawny audytu wewnętrznego (Legal character of internal audit), Państwo i Prawo, Vol. 73, No. 8 (2008)

Barcik A.: Mechanizm compliance - pytanie o miejsce i zasadność w strategiach CSR współczesnych organizacji (Compliance mechanism - a question of its place and justification in CSR strategies of modern organizations), Prace Naukowe Uniwersytetu Ekonomicznego we Wrocławiu No. 419: Wrocław, 2016

Braun T.: Unormowania compliance w korporacjach (Corporate compliance regulations), Warszawa: Wolters Kluwer Polska, 2017 
Ciak J.M., Voss. G.: Rola audytu wewnętrznego w sektorze publicznym i prywatnym wyniki badań w zakresie problemów wdrażania i korzyści z wykorzystania audytu wewnętrznego (The task of internal audit in public and private sector - findings regarding problems of implementation and benefits), Studia Prawno-Ekonomiczne, vol. 19, No. 104 (2017)

Czerwiński K.: Audyt wewnętrzny (Internal audit), Warszawa: Wydawnictwo InfoAudit Sp. z o.o., 2004

Gajewski D.: Opodatkowanie holdingów i grup kapitałowych (Holding and capital groups taxation), Warszawa: Dom Wy-dawniczy ABC, 2005

Kidyba A.: Komentarz aktualizowany do art. 301-633 Kodeksu spółek handlowych (Commercial companies code - Commentary), Warszawa: LEX/el., 2018

Kondrakiewicz T.: Holding jako forma współdziałania gospodarczego przedsiębiorstw (Holding as a form of economical cooperation of companies), Annales Universitatis Mariae Curie-Skłodowska, Sectio H, Oeconomia, vol. 45, no. 35, 2001

Kot L., Stokłosa A.: Pojęcie grupy kapitałowej w świetle ustawy - Prawo zamówień publicznych (The notion of capital group in the light of the public procurement act), Przegląd Prawa Handlowego, Vol. 24, No. 7 (2015)

Krasuski A., Skolimowska D.: Dane osobowe w przedsiębiorstwie (Personal data in company), Warszawa: LexisNexis, 2008

Krauss J.: Pozycja prawna komitetu audytu rady nadzorczej spółki akcyjnej (Legal situation of supervisory's board audit comitee in stock company), Przegląd Prawa Handlowego Vol. 21, No. 6 (2012)

Kwaśnicki R.L., Nilsson D.: Legalne działanie na szkodę spółki zależnej (Legal actions in damage of dependent company), Przegląd Prawa Handlowego Vol. 16, No. 12 (2007)

Makowicz B.: Compliance $\mathrm{w}$ przedsiębiorstwie (Compliance in company), Warszawa: Wolters Kluwer Polska, 2011

Nogalski B.: Waśniewski J., Miklaszewska, Outsourcing w holdingu - specyfika umowy o współpracy pomiędzy spółką-matką a spółką-córką jako warunek sukcesu firmy (Outsorcing inside holding - specifity of a cooperation deal between dominant and dependent company as a precondition of company's success), Za-rządzanie i Finanse, Vol. 11, No. 4 (2013)

Oplustil K.: Instrumenty nadzoru korporacyjnego (corporate governance) w spółce akcyjnej (Instruments of corporate governance in stock company), Warszawa: C.H. Beck, 2010

Pinior P.: Funkcje i odpowiedzialność komitetu audytu w strukturze organizacyjnej spółki akcyjnej (Functions and responsibility of audit comitee in the structure of stock company), in Bilewska K., Efektywność zarządzania i nadzoru w spółce handlowej. W poszukiwaniu optymalnego modelu ustroju spółki (Effectivity of governance and surveillence in commercial company. In search of the optimal company model), Warszawa: Wolters Kluwer Polska 2018

Piszcz A.: Grupa kapitałowa czy nie, czyli trudności z kwalifikacją i ich skutki (Capital group or not - difficulties in classification and their consequences), Internetowy Kwartalnik Antymonopolowy i Regulacyjny Vol. 2, No. 3 (2013) 
Romanowski M.: W sprawie potrzeby nowej regulacji prawa grup kapitałowych w Polsce (On the need of new regulation of capital groups in Poland), Przegląd Prawa Handlowego Vol. 17, No. 7 (2008)

Saunders E.J.: Kontrola wewnętrzna w bankowości (Inside control in banking), Warszawa: Fundacja Rozwoju Rachunkowości w Polsce, 1996

Sołtysiński S.: Czy regulować stosunki w holdingu (Should relations in holding be regulated), Rzeczpospolita, 8th October 2008

Szumański A.: [in:] Flisek A.: Kodeks spółek handlowych z wprowadzeniem (Commercial companies code with introduction), Warszawa: C. H. Beck, 2011

Szydło W.: Prawna dopuszczalność korzystania przez radę nadzorczą spółki akcyjnej z pomocy podmiotów zewnętrznych (Legal possibility of using outsiders help by stock company's supervisory board), Przegląd Prawa Handlowego Vol. 22, No. 6 (2013)

Wieczorek A.: Komitet audytu i komitet ds. wynagrodzeń w polskich bankach publicznych (Audit comitee and salary comitee in polish public banks), Studia PrawnoEkonomiczne, Vol. 14, No. 85 (2012)

Zięba M.: Czy w Polsce istnieje prawo grup spółek? (Does commercial companies law exist in Poland?), Newsletter 48/2016, http://kancelaria.mikulski.krakow.pl/?pl_nl-482016-czy-w-polsce-istnieje-prawo-grup-spolek-,225, (access: 10.09.2018)

\section{Legislation:}

Draft law - Code of commercial companies and the law on the National Court Register of 22 March 2010

The Regulation (EU) No 537/2014 of the European Parliament and of the Council of 16 April 2014 on specific requirements regarding statutory audit of public-interest entities and repealing Commission Decision 2005/909/EC, Official Journal L 158/77 of 27.05.2014

The Law of 29 January 2004 on public procurement, Journal of Laws of 2017, item 1579, as ammended

The Law of 15 February 1992 on corporate tax, Journal of Laws of 2018, item 1036, as ammended

The Law of 16 February 2007 on the protection of competition and consumer, Journal of Laws of 2018, item 798, as ammended

The Law of 18 March 2010 on particular rights of minister competent for en-ergy matters and their execution in some capital companies or capital groups conducting business activity in sectors of electricity, petroleum and gas fuels, Journal of Laws of 2016, item 2012, as ammended

The Law of 11 May 2017 on statutory auditors, audit companies and public supervision, Journal of Laws of 2017, item 1089, as ammended

The Law of 29 July 2005 on trading financial instruments, Journal of Laws of 2017, item 1768 , as ammended

The Law of 29 September 1994 on accounting, Journal of Laws of 2018, item 395, as ammended

The Law of 16 December 2016 on the principles of administering state proper-ty, Journal of Laws of 2018, items 1182, as ammended 
Recommendation of the Commission 2004/913/EC fostering an appropriate regime for the remuneration of directors of listed companies, Official Journal L 385/55 of 29.12.2004

\section{Miscellaneous:}

The Good Practices in Public Companies 2002

The Good Practices in GPW Listed Companies 2016, https://www.gpw.pl/pub/GPW/files/PDF/GPW_1015_17_DOBRE_PRAKTYKI_v2.p df (access: 10.09.2018)

Document on Projekt ustawy o zmianie ustawy - Kodeks spółek handlowych i ustawy o Krajowym Rejestrze Sądowym, Przegląd Corporate Governance 2009, No. 4

Document on Projekt ustawy o zmianie ustawy - Kodeks spółek handlowych i ustawy o Krajowym Rejestrze Sądowym, Przegląd Corporate Governance 2010, No. 2

Ruling of the Appeal Court in Katowice of 3 December 2012, V ACa 702/12, LEX No. 1236676 